\title{
Asztmás gyermekek egészségmagatartásának vizsgálata a média- és internethasználat és az önértékelés dimenziói mentén
}

\author{
Józsa Tamás ${ }^{1}$ - Papp Ágnes dr. ${ }^{1}$ - Gönczi Ferenc dr. ${ }^{2}$ \\ Balla György dr. ${ }^{1}$ - Nagy Beáta Erika dr. ${ }^{1}$ \\ Debreceni Egyetem, ' Általános Orvostudományi Kar, Gyermekgyógyászati Intézet, \\ ${ }^{2}$ Kenézy Gyula Egyetemi Kórház, Debrecen
}

Bevezetés: Az asthma bronchiale a szakirodalom alapján a szomatikus és a pszichés tényezók összefonódásával jellemezhető. Lényeges, hogy ezen betegcsoport egészségmagatartására releváns hatással lehet a szociális deficiteket kompenzáló virtuális világ.

Célkitüzés: Célunk, hogy azonosítsunk olyan faktorokat, amelyeknek köszönhetően a jövőbeli intervenciók hatékonyabbá tehetik a betegellátást. Vizsgálni kívánjuk a közösségimédia- és internethasználatot, az önértékelést és a kötődéssel összefüggő szociodemográfiai tényezőket.

Módszer: A vizsgálathoz az általunk magyarra adaptált Facebook Használati Kérdőívet, a Problémás Internethasználat Kérdőívet, a Rosenberg Önbecsülés Skálát és egy szociodemográfiai kérdőívet alkalmaztunk. A kutatásba 10 és 18 év közötti, 175 fó, asthma bronchialéban szenvedő gyermeket vontunk be (92 fiú, 83 lány).

Eredmények: A Facebook használata elterjedtebb a lányok, a bölcsődébe járt, illetve a nem szoptatott gyermekek, mint a fiúk, a bölcsődébe nem járt, illetve a szoptatott gyermekek körében $(p<0,01)$. Az internethasználatra ezek a tényezők nem gyakoroltak szignifikáns befolyást. Már az 1-7 napig tartó szoptatás is kötődést megerősítő hatással bír, ami megmutatkozik a kisebb mértékű közösségimédia-használatban, összevetve a nem szoptatott gyermekek értékeivel $(\mathrm{p}<0,01)$. Közepes erôsségü, negatív kapcsolatot találtunk a Facebook-használat és a gyermekek száma a családban $(p=-0,400 ; p<0,01)$, illetve az önértékelés és a Facebook-használat között $(p=-0,475 ; p<0,01)$. A lakóhely nagysága és a Facebook-használat közepes erősségű, pozitív korrelációval jellemezhető $(\rho=0,492 ; p<0,01)$.

Következtetések: A kötődési hiányokkal jellemezhető asthmás fiatalok valószínúbben használják a szociális visszacsatolásokat (feedbackeket) fokozottan nyújtó közösségi médiát önértékelésük és szociometriai státuszuk kompenzálására, főképpen a lányok. Védőfaktorként az élő, személyes kapcsolatok meglétét, valamint a korai életévekbeli anya-gyermek kapcsolatot emelhetjük ki.

Orv Hetil. 2018; 159(47): 1971-1980.

Kulcsszavak: asthma bronchiale, egészségmagatartás, internethasználat, önértékelés

\section{Studying the health behavior of asthmatic children regarding the dimensions of media and internet usage and self-esteem}

Introduction: According to the literature, somatic and psychological factors are connected with asthma bronchiale. The health behavior of these patients can be influenced by the virtual world.

Aim: We wish to analyze social media and internet usage, self-esteem and sociodemographic data connected to attachment.

Method: For our research, the Facebook Intensity Scale, the Problematic Internet Usage Questionnaire, the Rosenberg Self-Esteem Scale and a socio-demographic questionnaire were used. We interviewed 175 asthmatic children from the age of 10 to 18 ( 92 boys, 83 girls).

Results: Asthmatic girls, children who went to daycare (under the age of 3 ) and who were not breastfed use Facebook more than boys, children who stayed at home instead of daycare and who were breastfed $(\mathrm{p}<0.01)$. There is no difference in their internet usage. Breastfeeding (even if it only lasted for 1-7 days) can strengthen attachment which is 
shown in our results regarding social media usage compared with children who were not breastfed $(\mathrm{p}<0.01)$. A negative relation with medium strength was found between the number of siblings $(p=-0.400 ; p<0.01)$ and the selfesteem and Facebook usage $(\rho=-0.475 ; \mathrm{p}<0.01)$. There is a positive correlation between Facebook usage and the size of the place the children live in $(\rho=0.492 ; \mathrm{p}<0.01)$.

Conclusions: Asthmatic youth use social media more frequently which provides social feedback to compensate their self-esteem, especially by girls. As protection factors, we can emphasize the existence of human relationships and the importance of an early mother-child bond.

Keywords: asthma bronchiale, health behavior, internet usage, self-esteem

Józsa T, Papp Á, Gönczi F, Balla Gy, Nagy BE. [Studying the health behavior of asthmatic children regarding the dimensions of media and internet usage and self-esteem]. Orv Hetil. 2018; 159(47): 1971-1980.

(Beérkezett: 2018. május 30.; elfogadva: 2018. július 1.)

\section{Rövidítések}

FHK = Facebook Használati Kérdőív; Ig = immunglobulin; PIHK = Problémás Internethasználat Kérdőív; RSES = $($ Rosenberg Self-Esteem Scale) Rosenberg Önbecsülés Skála

Az asthma bronchiale a légutak olyan krónikus gyulladásos megbetegedése, amely nagyfokú heterogenitással jellemezhető $[1]$, s kialakulásában érzelmi-szervi sérülékenység és genetikai-környezeti tényezők egyaránt szerepet játszanak [2]. A legfrissebb epidemiológiai adatok szerint e megbetegedés gyakorisága továbbra is folyamatos, lassú növekedést mutat [3,4]. Az asztma etiológiájának folyamatában több sejt és sejtproduktum vesz részt: jellemző a hízósejt-aktiváció, valamint az eozinofil sejtes és CD4+ lymphocytás gyulladás [5]. Vizsgálatok szerint az asztmás gyermekek stresszre adott magasabb humorális válasszal [6] és magasabb allergénspecifikus IgE-szinttel jellemezhetők [7], s rendszerint Th2-citokin válaszprofilúak [8]. Emellett a különféle noxákkal szembeni fokozott válaszkészség [9], valamint a glükokortikoidok és katecholaminok szisztémás egyensúlyának módosulása tapasztalható esetükben [10]. A betegség kialakulását befolyásolhatja az úgynevezett higiéniaelmélet, mely szerint a metropolita-életmód elterjedése miatt a gyermekeket csecsemőkorukban kevés stimuláló inger éri a levegőben megjelenő mikrobiológiai spektrumot tekintve (túl kevés allergén van a levegöben), emiatt immunrendszerük alul fog múködni [11]. $\mathrm{Az}$ asthma bronchiale klinikai képét a nehézlégzés, a mellkasi feszülés, a köhögésrohamok és az éjszakai felriadás mint szomatikus panaszok tovább árnyalják [12]. Mindezek tartósan fennállhatnak tünetmentes állapotban és normális légzésfunkció mellett is, de a kezelés hatására mérséklődhetnek vagy teljesen megszúnhetnek. Az asztmában szenvedók életminősége - gyermekkorban különösen - kiemelt jelentőségú, hiszen a jövőjükre nézve rendszeres orvosi kontrollt, fokozott otthoni-intézményi figyelmet, társas megkülönböztetést élhetnek át, azaz szükséges adaptálódniuk ezekhez a helyzetekhez. A pszichés jóllét meghatározó a betegségség folya- matában (például szorongás, depresszió) [13], emiatt fontos a biopszichoszociospirituális modell figyelembevétele annak kialakulásában és kezelésében [14]. Lényeges továbbá a gyermekek - és életkoruktól függő́en az ő szüleik - esetében a „health literacy” (egészségmúveltség) bővítése [15]. Ennek egyik fontos eleme, hogy az asthmás gyermekek sporttevékenységre szoktatásában az úszás megfelelő szerepet töltsön be: kutatások szerint a rendszeres úszásfoglalkozás többségében javítja, de semmiképpen sem rontja fizikai állapotukat, ellenben fejleszti állóképességüket, elősegíti a „well-being” (szubjektív jóllét) átélését, és facilitálja a csoporthoz tartozás érzését [16].

További fontos szempont, hogy a gyermeket az ôt körülvevő miliővel kölcsönhatásban szemléljük, azaz az úgynevezett „pszichoszomatikus családoknak” a múködésére is megfeleló figyelem irányuljon. Ezek a családok sajátos interakciós mintázatokkal jellemezhetók, amelyek hozzájárulnak az asztma súlyosbodásához és konfliktusokkal idóben is összekapcsolható jelentkezéséhez (szinkronicitás). A veszekedésekkel terhelt környezetben a gyermekek rohamainak száma és súlyossága megváltozhat [17]. Ugyanígy gyakori lehet a parentifikáció jelenségével kapcsolatban - amikor a gyermek maga kerül családon belül szülői szerepbe -, hogy a gyermek a rá nehezedő nyomás miatt „produkálhat” rohamot [18]. Gyakran a triangulációs helyzetekben a gyermek tünete hozhatja meg a stabilitást (olyan szituációkban, amikor két családtag között a feszültségból eredő distabilitás egy harmadik félnek köszönhetően átmenetileg megszúnik) [19]. A pszichoanalitikus modellek szerint az anya nem megfelelő kötődési viselkedése okozhatja a testnyelven történő érzelemkifejezést. Nemes szerint a legalapvetőbb életösztön, a légzés nem megfelelő múköódése az eriksoni ősbiztonság 0-3 éves korban történő sérülésével magyarázható [20]. Hermann elméletéből kiindulva Klaniczay szoros összefüggést talált a megkapaszkodási ösztön frusztrációja és az édesanya nem megfelelő kötődési magatartása között [21].

Jelenkori, kötődéssel kapcsolatos vizsgálatok szerint is a közvetlen kontaktus, a „skin to skin” szoptatás a legha- 
tékonyabb preventív faktor az asztmával kapcsolatban: azoknak a gyermekeknek a körében, akik lefejt tejet is kaptak (azaz nem kizárólag közvetlenül szoptatták óket), 43\%-kal, akik pedig csak tápszert kaptak, 79\%-kal nőtt a valószínűsége, hogy asztmával diagnosztizálják őket. Ennek a lehetséges biológiai magyarázata mellett (megváltozik az anyatej összetétele a fagyasztás és tárolás következtében, csökken annak antioxidáns tulajdonsága és a benne lévő vitaminok mennyisége, alacsonnyá válik az IgA-aktivitás) a szerzők felvetik a pszichológiai tényezők, a biztonságos anya-gyermek kapcsolat és a kötődés relevanciáját [22]. Az anya-magzat kapcsolatanalízis objektív mérésekkel bizonyította, hogy a kölcsönös anyagyermek viszony már a prenatális életévekben megkezdődik, és oda-vissza hat [23]. A születés után az elsődleges és másodlagos interszubjektivitás kialakulása miatt elengedhetetlen a közvetlenül a gyermekkel töltött minőségi idő [24]. Következésképp a család preventív volta az addikciókkal kapcsolatban (például internetfüggőség) lényeges tényező: a magányosság, a magára hagyatottság fokozottan hajlamosíthat már gyermekkortól kezdve a kompenzáló viselkedésmintázatokra [25]. A házasság, a megtartó családi kapcsolatok és a szociális háló egészségvédő hatásait mind magyar, mind külföldi kutatások igazolták [26, 27].

A média- és internethasználattal kapcsolatban metaanalízisek mutatták ki, hogy a képernyőn látott diszfunkcionális viselkedésmintázatok tudattalanul identifikációs modellé válhatnak [28]. Szignifikáns tényező napjainkban a cyberbullying jelensége (online módon történő zaklatás), amelynek a nem megfelelő társas kapcsolatokkal felvértezett gyermekek könnyedén áldozatául eshetnek. Kutatások bizonyítják, hogy a szülők többsége egyáltalán nem korlátozza és felügyeli gyermeke internethasználatát [29]. Különösképp veszélynek vannak kitéve azok, akiknek az önértékelése alacsony, így kompenzatorikus célzattal igyekeznek a virtuális világban olyan szociometriai státuszt elérni, amellyel a valóságban nem rendelkeznek [30]. A Facebook világszerte az az eszköz, amely alapjaiban épült be a mindennapok kommunikációs csatornái közé, és általa a legkönnyebben kaphat az illető jutalmazó szociális visszajelzéseket „like”-ok, „tag”-ek, kommentek, megosztások formájában [31]. Használatával kapcsolatban a fő motiváló erő a közösségi élmény megélése [32]. Az „általános” internethasználatról ellenben nem jelenthető ki, hogy a valahová tartozás érzése motiválná elsősorban [33].

\section{Módszer}

\section{Célkitüzés}

A jelen kutatás egy olyan pilotprojekt folytatása [34] és egyben egy nagyobb vizsgálat részeredményének összefoglalása, amelynek célja, hogy az asthma bronchialéban szenvedő gyermekekre fókuszálva meghatározzunk prediktív és preventív faktorokat, mert az azok alapján szer- vezett intervenciók segíthetnek a kezelés hatékonyságának növelésében (például szülőcsoportok szervezése, gyermekek szociális készségeinek fejlesztése). Az eddig kapott adataink szignifikáns eltérést mutattak az asthma bronchialéban szenvedő gyermekek javára a sine morbo kontrollcsoporttal összevetve a Facebook-használatukat tekintve. Mindez az internethasználatukban csak tendenciaként volt jelen [34]. Célunk, hogy megismerjük az asztmás gyermekek Facebook- és internethasználatát és önértékelését, valamint ezek összefüggéseit e betegcsoport olyan szociodemográfiai adataival, amelyek a kora gyermekkori anya-gyermek kapcsolatot írják le (a szoptatás időtartama, a bölcsődébe adás időtartama, a testvérek száma a családban, a lakóhely nagysága).

\section{Kérdésfeltevéseink, hipotézisek}

1. Releváns nemi különbségeket feltételezünk a mintában. Hipotézisünk, hogy a fiúk kevesebbet használják a Facebookot, mint a lányok. Ennek okát fejlődéslélektani sajátosságokban kereshetjük: a lányokra jellemzőbb a fokozott szociabilitás, a közösség véleményének fontossága a prepubertás-, pubertáskorban. Mindezen sajátosság az általános internethasználatuk kapcsán nem mutatkozik meg. Emellett a lányok önértékelése alacsonyabb lehet: ennek oka és következménye egyaránt lehet a magasabb közösségimédia-használat [35].

2. A bölcsődébe több időt járt gyermekek Facebookhasználata magasabb, mint azoké, akik nem jártak ilyen intézménybe. Minél több időt töltött a gyermek bölcsődében, annál erősebb ez az összefüggés. Az internethasználatukban nem mutatkozik ilyen jellegü differencia. Emellett a bölcsődébe jártak önértékelése szignifikánsan alacsonyabb, mint a bölcsődébe nem járt gyermekeké. Ezek a relációk az asztmás gyermekek kora gyermekkori kötődésével kapcsolatos nehézségeken alapulva alakulhatnak így [36].

3. A gyermekek szoptatásával kapcsolatban hipotézisünk, hogy azok, akiket csecsemőkorukban nem szoptattak, Facebook-használatukban, valamint önértékelésükben szignifikánsan eltérnek azoktól, akiket szoptattak. Mindezen differencia a szoptatásuk időtartamával összefüggően változik. Az internethasználatukra mindez nincsen hatással. A várt eredmények a kora gyermekkori anya-gyermek kötődés miatt alakulhatnak így [37].

4. Negatív korreláció mutatható ki a családban lévő gyermekek száma és a Facebook-használat között, mivel a nagycsalád megtartó szociális hálóként funkcionálhat a közösségimédia-használat mint kompenzatorikus magatartás szempontjából [38]. Az internethasználattal kapcsolatban ilyen összefüggést nem várunk.

5. A lakóhely nagysága és a Facebook-használat mértéke között pozitív korreláció tapasztalható. Ez kevéssé vagy egyáltalán nem tapasztalható az internethasználattal összefüggésben. Mindez feltételezhetően a kisebb települések „élőbb”, személyesebb kapcsolatrendszere miatt alakulhat így [39]. 
6. Negatív korreláció mutatható ki az önértékelés mértéke és a Facebook-használat között, míg ez a tendencia csak kisebb mértékben tapasztalható az önértékelés és az internethasználat között. Ennek fő oka a közösségi médiában másokhoz történő hasonlítgatás (relativizálás), valamint az alapvetően pozitív megerősítések keresése mint kompenzatorikus magatartásforma [40].

\section{Vizsgálati minta}

A kutatásba 10 és 18 év közötti, 182 fó, asthma bronchialéban szenvedő gyermeket és szüleiket vontuk be. Közülük 175 fő töltötte ki értékelhetően a kérdőíveket. A vizsgálati minta a Debreceni Egyetem Klinikai Központ Gyermekgyógyászati Klinikájának Pulmonológiai Szakrendelésére járókból és a Debreceni Egyetem Kenézy Gyula Egyetemi Kórház Pulmonológiai Szakrendelésére járó gyermekekből állt (összesen 120 fő), emellett 55 asztmás gyermek online módon töltötte ki a kérdőíveket. A vizsgálati mintánkban nem szerepeltek olyan asztmás gyermekek, akik esetében a betegségük súlyossága kizárta volna a közösségi sporttevékenységekben történó részvételt. A kutatás a Regionális és Intézményi Kutatásetikai Bizottságtól származó (4741-2017) és az Egészségügyi Tudományos Tanács Tudományos és Kutatásetikai Bizottsága által kiállított engedélyekkel (14399-4 2018/EKU) rendelkezik.

\section{Vizsgálati eszközök}

A vizsgálati személyekkel a magyarra ebben a kutatásban adaptált Facebook Használati Kérdőívet (FHK [41]), a Problémás Internethasználat Kérdőívet (PIHK [42]), a Rosenberg Önbecsülés Skálát (RSES [43]), egy általunk készített általános szociodemográfiai kérdőívet és egy pszichológiai anamnézist vettünk fel. Az FHK olyan kérdőív, amelynek önkitöltése során a személynek Facebook-használattal kapcsolatos kérdésekre kell felelnie. A fizikai tevékenységre (például napi használat) és a releváns pszichológiai, csoporthoz tartozást detektáló faktorokra is fókuszál („Úgy érzem, része vagyok a facebookozók közösségének”). Minél magasabb a válaszok összpontszám, annál inkább mondható az illetőre, hogy túlzott mértékben használja a Facebookot. A kérdőív minimálisan elérhetó értéke 0 , a maximális pontszáma pedig 30. A PIHK eszköz jól használható mind gyermekek, mind fiatalok esetében. 3 alskálája van (obszesszió, elhanyagolás, kontrollzavar), amelyek együttes értéke adja meg az összpontszámot: ez minél magasabb, annál inkább jelez fokozott internethasználatot, addikciót. A minimális pontszám 0, a maximális 90. Az RSES 10 itemből áll, és az önszeretetet, az önelfogadást méri. A 10 kérdésre adott válaszok összpontszáma adja meg a végső értéket, amely minél magasabb, annál pozitívabb az egyén önértékelése. A minimális pontszám 10 , a maximális 40. Az általános szociodemográfiai adatokra kérdező kérdéssor és a pszichológiai anamnézis kérdései
Asztmás gyermekek a vizsgálatban

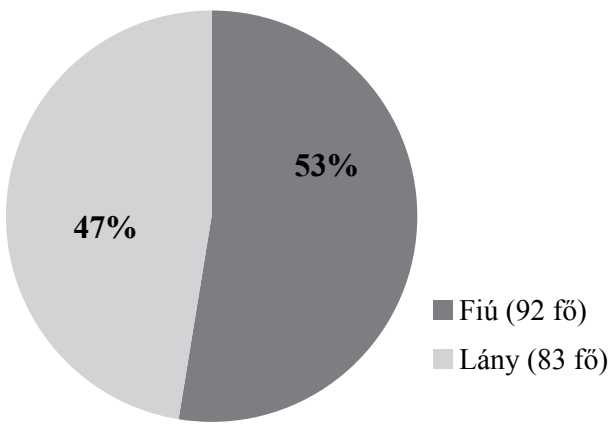

1. ábra $\quad$ A vizsgálati minta nemek szerinti megoszlása

közül a bölcsődébe járás és a szoptatás időtartama, a családban élő gyermekek száma, valamint a lakóhely nagysága válaszok relevánsak.

$\mathrm{Az}$ eredmények statisztikai feldolgozásához az R statisztikai program 3.5.0-s verzióját használtuk. A használt statisztikai módszert és annak indoklását az eredmények ismertetése során feltüntettük.

\section{Eredmények}

Vizsgálati mintánk nemek szerinti eloszlását grafikusan ábrázoltuk (1. ábra). Az első hipotézisünk kapcsán kapott eredményeket az 1 táblázatban foglaltuk össze. Adataink nem követtek normáleloszlást (Shapiro-Wilkpróba), ezt követően Mann-Whitney-próbát használtunk. Hipotézisünk igaznak bizonyult: az adatok azt mutatják, hogy a fiúk Facebook-használata szignifikáns mértékben kisebb, mint a lányoké (13,73 vs. 16,73; $\mathrm{p}<0,01) . \mathrm{Az}$ internethasználati átlagpontszámban nem mutatható ki jelentős különbség (31,78 vs. 33,19; p>0,33). A fiúk önértékelése szignifikáns mértékben magasabb, mint a lányoké $(29,86$ vs. 27,$26 ;$ p<0,01).

A második hipotézisünk kapcsán a gyermekeket 5 csoportba soroltuk: A) nem járt bölcsődébe; B) 1-4 hétig járt bölcsődébe; C) 1-6 hónapig járt bölcsődébe; D) 7-12 hónapig járt bölcsődébe; E) 13-18 hónapig járt bölcsődébe. Ennek grafikus ábrázolása a 2. ábrán látható. Annak teszteléséhez, hogy az egyes csoportokban a Facebook- és az internethasználat, valamint az önértékelés eltérő mértékü-e, Kruskal-Wallis-próbát kellett alkalmazni az adatok nem normál módon történő eloszlása miatt (Shapiro-Wilk-próba). Ezt követően az egyes cso\begin{tabular}{l|l} 
1. táblázat & $\begin{array}{l}\text { A nemek közötti különbség a Facebook- és az internethasználat, } \\
\text { valamint az önértékelés dimenziói mentén }\end{array}$
\end{tabular}

\begin{tabular}{lccc}
\hline & $\begin{array}{c}\text { Facebook-haszná- } \\
\text { lati átlagpontszám } \\
(\max .30)\end{array}$ & $\begin{array}{c}\text { Internethasználati } \\
\text { átlagpontszám } \\
(\max .90)\end{array}$ & $\begin{array}{c}\text { Az önértékelés } \\
\text { átlagpontszáma } \\
(\max .40)\end{array}$ \\
\hline Fiúk & 13,7 & 31,7 & 29,8 \\
Lányok & 16,7 & 33,1 & 27,2 \\
\hline Különbség & $\mathrm{p}<0,01^{* *}$ & $\mathrm{p}>0,33$ & $\mathrm{p}<0,01^{*}$ \\
\hline
\end{tabular}

**szinten szignifikáns (szigorú szignifikanciaszint) 


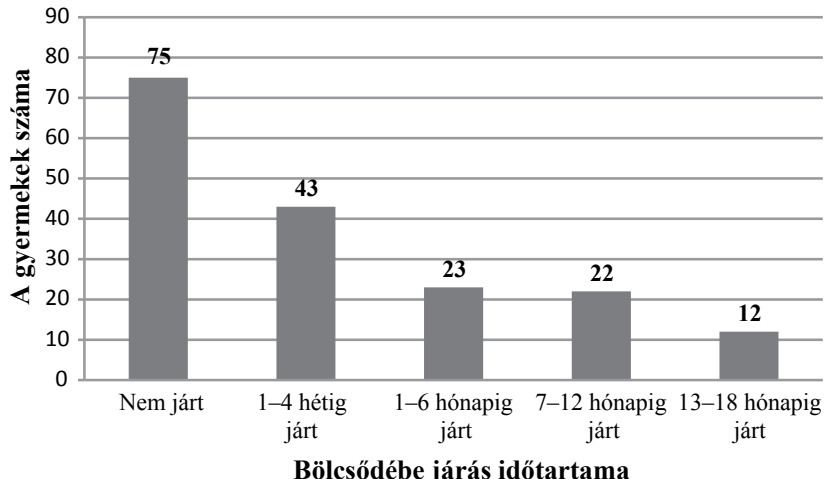

2. ábra

A vizsgálatba bevont gyermekek bölcsődébe járásának időtar-

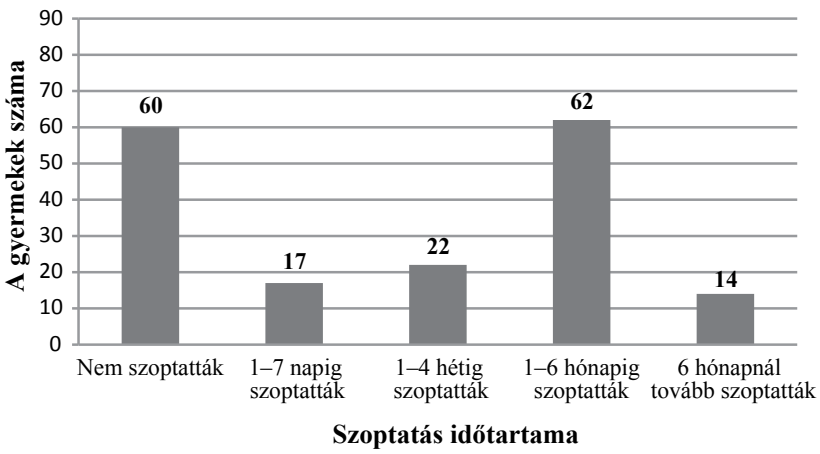

3. ábra

| A vizsgálatba bevont gyermekek szoptatásának időtartama

portok összehasonlítására Mann-Whitney-próbát alkalmaztunk. A kapott eredményeinket a 2. és a 3. táblázatban foglaltuk össze. A második hipotézisünk kapcsán az eredmények a vártnak megfelelően alakultak. A bölcsődébe járt gyermekek Facebook-használata szignifikánsan magasabbnak bizonyult (csoportátlag: 19 a 30-ból), mint azoké, akik nem jártak ilyen intézménybe $(12,4$ a 30-ból; p<0,01), s ez az ott töltött időtartammal fokozatosan nőtt. A differencia az internethasználatuk kapcsán nem mutatkozott meg jelentős mértékben (33,6 vs. 30,4 a 90-ből). A bölcsődébe jártak önértékelése szignifikánsan alacsonyabb volt (25,9 a 40-ből), mint azoké, akik nem jártak ilyen intézménybe (31 a 40-ből; p<0,01). Ez az ott töltött időtartam mértékével párhuzamosan csökkent. Az egyes csoportok részletes összevetése során látszik, hogy az 1-4 hétig tartó intézményi tartózkodás még nem jelentett szignifikánsan magasabb Facebookhasználatot és alacsonyabb önértékelést a bölcsődébe nem jártak csoportjával összevetve, hanem tendenciaszintût, ám az egy hónapnál több ideig történő intézményi tartózkodás már szigorú szignifikanciaszintet használva is jelentősnek bizonyul. A Facebook-használat minden további csoport között szignifikánsan nagyobb volt; az önértékelés csökkenése pedig tendenciaszintú, de egyenletesen csökkenő maradt.

A harmadik hipotézisünkben a gyermekeket 5 csoportba soroltuk: A) nem szoptatták; B) 1-7 napig szoptatták; C) 1-4 hétig szoptatták; D) 1-6 hónapig szoptatták; E) 6 hónapnál tovább szoptatták. Ennek grafikus ábrázolása a 3. ábrán látható. Annak teszteléséhez, hogy az egyes csoportokban a Facebook- és az internethasználat, valamint az önértékelés eltérő mértékü-e, KruskalWallis-próbát alkalmaztunk az adatok nem normáleloszlása miatt (Shapiro-Wilk-próba). Az egyes csoportok összehasonlítására Mann-Whitney-próbát alkalmaztunk. A kapott eredményeinket a 4. és 5. táblázatban foglaltuk össze. A kapott eredmények az előzetesen megfogalmazott hipotézist támasztják alá. Az adatok szerint azon gyermekek, akiket akár csak rövid ideig is (1-7 napig) szoptattak, szignifikánsan kevesebb Facebook-használattal jellemezhetők, mint azok, akiket egyáltalán nem szoptattak (14,59 vs. 20,03; p<0,01). Ez a különbség az internethasználatukban nem mutatkozott meg szignifikáns mértékben. A Facebook-használatot tekintve, a szoptatott csoportokat a nem szoptatott csoporttal öszszehasonlítva, szignifikánsan magasabb eredményt kap-

2. táblázat |A bölcsődébe járt és nem járt gyermekek Facebook- és internethasználata és önértékelése közötti átlagpontszámok

\begin{tabular}{lccc}
\hline & $\begin{array}{c}\text { Facebook- } \\
\text { használati } \\
\text { átlagpontszám } \\
(\text { max. 30) }\end{array}$ & $\begin{array}{c}\text { Internet- } \\
\text { használati } \\
\text { átlagpontszám } \\
(\text { max. 90) }\end{array}$ & $\begin{array}{c}\text { Az önértékelés } \\
\text { átlagpont- } \\
\text { száma } \\
(\text { max. 40) }\end{array}$ \\
\hline Nem járt bölcsődébe & 12,4 & 30,4 & 31 \\
1-4 hétig járt & 13,5 & 35,1 & 29 \\
1-6 hónapig járt & 16,4 & 33 & 27,3 \\
7-12 hónapig járt & 20,5 & 33,1 & 25,7 \\
13-18 hónapig járt & 25,6 & 33,3 & 21,9 \\
\hline $\begin{array}{l}\text { Az 5 csoport } \\
\text { különbsége }\end{array}$ & $\mathrm{p}<0,01$ ** & $\mathrm{p}>0,39$ & $\mathrm{p}<0,01$ * \\
\hline
\end{tabular}

*szinten szignifikáns

3. táblázat |A bölcsődében töltött idő hatása a Facebook- és internethasználatra és az önértékelésre

\begin{tabular}{lccc}
\hline $\begin{array}{l}\text { A csoportok } \\
\text { összehasonlítása }\end{array}$ & $\begin{array}{c}\text { A Facebook- } \\
\text { használat } \\
\text { különbsége }\end{array}$ & $\begin{array}{c}\text { Az internethasz- } \\
\text { nálat különbsége }\end{array}$ & $\begin{array}{c}\text { Önértékelésbeli } \\
\text { különbség }\end{array}$ \\
\hline A és B & $\mathrm{p}=0,22$ & $\mathrm{p}=0,07$ & $\mathrm{p}=0,22$ \\
A és C & $\mathrm{p}<0,01^{* *}$ & $\mathrm{p}=0,2$ & $\mathrm{p}<0,05^{*}$ \\
A és D & $\mathrm{p}<0,01^{* *}$ & $\mathrm{p}=0,54$ & $\mathrm{p}<0,01^{*}$ \\
A és E & $\mathrm{p}<0,01^{* *}$ & $\mathrm{p}=0,96$ & $\mathrm{p}<0,01^{*}$ \\
B és C & $\mathrm{p}<0,01^{* *}$ & $\mathrm{p}=0,72$ & $\mathrm{p}=0,28$ \\
B és D & $\mathrm{p}<0,01^{* *}$ & $\mathrm{p}=0,49$ & $\mathrm{p}<0,05^{*}$ \\
B és E & $\mathrm{p}<0,01^{* *}$ & $\mathrm{p}=0,52$ & $\mathrm{p}<0,01^{* *}$ \\
C és D & $\mathrm{p}<0,01^{* *}$ & $\mathrm{p}=0,83$ & $\mathrm{p}=0,44$ \\
C és E & $\mathrm{p}<0,01^{* *}$ & $\mathrm{p}=0,72$ & $\mathrm{p}<0,05^{*}$ \\
D és E & $\mathrm{p}<0,01^{* *}$ & $\mathrm{p}=0,8$ & $\mathrm{p}=0,067$ \\
\hline
\end{tabular}

Jelmagyarázat: $\mathrm{A}=$ nem járt bölcsődébe; $\mathrm{B}=1-4$ hétig járt bölcsődébe; $\mathrm{C}=1-6$ hónapig járt bölcsődébe; $\mathrm{D}=7-12$ hónapig járt bölcsődébe; $\mathrm{E}=13-18$ hónapig járt bölcsődébe

*szinten szignifikáns

**szinten szignifikáns (szigorú szignifikanciaszint) 
A szoptatás időtartamának összefüggése a Facebook- és internethasználattal és az önértékeléssel

\begin{tabular}{|c|c|c|c|}
\hline & $\begin{array}{l}\text { Facebook- } \\
\text { használati } \\
\text { átlagpontszám } \\
(\max .30)\end{array}$ & $\begin{array}{l}\text { Internethaszná- } \\
\text { lati átlagpont- } \\
\text { szám (max. 90) }\end{array}$ & $\begin{array}{l}\text { Az önértékelés } \\
\text { átlagpontszáma } \\
\quad(\max .40)\end{array}$ \\
\hline Nem szoptatták & 20,03 & 35,6 & 25,7 \\
\hline $\begin{array}{l}\text { 1-7 napig } \\
\text { szoptatták }\end{array}$ & 14,59 & 30,5 & 28,4 \\
\hline $\begin{array}{l}\text { 1-4 hétig } \\
\text { szoptatták }\end{array}$ & 13,09 & 33,96 & 28,5 \\
\hline $\begin{array}{l}\text { 1-6 hónapig } \\
\text { szoptatták }\end{array}$ & 12,18 & 30,45 & 30,94 \\
\hline $\begin{array}{l}6 \text { hónapnál tovább } \\
\text { szoptatták }\end{array}$ & 11,5 & 28,15 & 32,86 \\
\hline $\begin{array}{l}\text { Az } 5 \text { csoport } \\
\text { különbsége }\end{array}$ & $\mathrm{p}<0,01$ ** & $\mathrm{p}>0,11$ & $\mathrm{p}<0,01$ ** \\
\hline
\end{tabular}

**szinten szignifikáns (szigorú szignifikanciaszint)

5. táblázat | A szoptatás időtartamának hatása a Facebook- és internethasználatra és az önértékelésre

\begin{tabular}{lccc}
\hline $\begin{array}{l}\text { A csoportok } \\
\text { összehasonlítása }\end{array}$ & $\begin{array}{c}\text { A Facebook- } \\
\text { használat } \\
\text { különbsége }\end{array}$ & $\begin{array}{c}\text { Az internethasz- } \\
\text { nálat különbsége }\end{array}$ & $\begin{array}{c}\text { Önértékelésbeli } \\
\text { különbség }\end{array}$ \\
\hline A és B & $\mathrm{p}<0,05^{*}$ & $\mathrm{p}=0,17$ & $\mathrm{p}=0,14$ \\
A és C & $\mathrm{p}<0,01^{* *}$ & $\mathrm{p}=0,67$ & $\mathrm{p}=0,16$ \\
A és D & $\mathrm{p}<0,01^{*}$ & $\mathrm{p}=0,05$ & $\mathrm{p}<0,01^{*}$ \\
A és E & $\mathrm{p}<0,01^{* *}$ & $\mathrm{p}=0,06$ & $\mathrm{p}<0,01^{*}$ \\
B és C & $\mathrm{p}=0,62$ & $\mathrm{p}=0,4$ & $\mathrm{p}=1$ \\
B és D & $\mathrm{p}=0,4$ & $\mathrm{p}=0,93$ & $\mathrm{p}<0,05^{*}$ \\
B és E & $\mathrm{p}=0,48$ & $\mathrm{p}=0,43$ & $\mathrm{p}=0,14$ \\
C és D & $\mathrm{p}=0,9$ & $\mathrm{p}=0,17$ & $\mathrm{p}=0,21$ \\
C és E & $\mathrm{p}=0,75$ & $\mathrm{p}=0,08$ & $\mathrm{p}=0,9$ \\
D és E & $\mathrm{p}=0,34$ & $\mathrm{p}=0,35$ & $\mathrm{p}=0,46$ \\
\hline
\end{tabular}

Jelmagyarázat: A = nem szoptatták; $\mathrm{B}=1-7$ napig szoptatták, C = 1-4 hétig szoptatták; $\mathrm{D}=1-6$ hónapig szoptatták; $\mathrm{E}=6$ hónapnál tovább szoptatták

*szinten szignifikáns

**szinten szignifikáns (szigorú szignifikanciaszint)

tunk az utóbbiak javára $(12,84$ vs. 20,$03 ; \mathrm{p}<0,01)$. Az internethasználata a szoptatott csoportoknak $(30,77)$ és a nem szoptatott csoportnak $(35,6)$ nem mutat szignifikáns eltérést. Az önértékelésük az akár csak rövid ideig is szoptatott gyermekeknek magasabb volt, mint azoké, akiket nem szoptattak, ám mindez nem bizonyult szignifikánsnak (28,4 vs. 25,7; p<0,164). Az 1 hónapos szoptatás már szignifikánsan magasabb önértékelést mutatott a nem szoptatott csoporthoz képest (30,94 vs. 25,7 ; $\mathrm{p}<0,01)$.

A negyedik hipotézisünkhöz a családban lévő gyermekek számát a 4. ábrán tüntettük fel grafikus módon. Jelen hipotézisünkben, mivel adataink esetében sérült a normalitáskövetelmény (Shapiro-Wilk-próba), a Spearman-felé rangkorrelációt használtuk. A kapott korreláci-

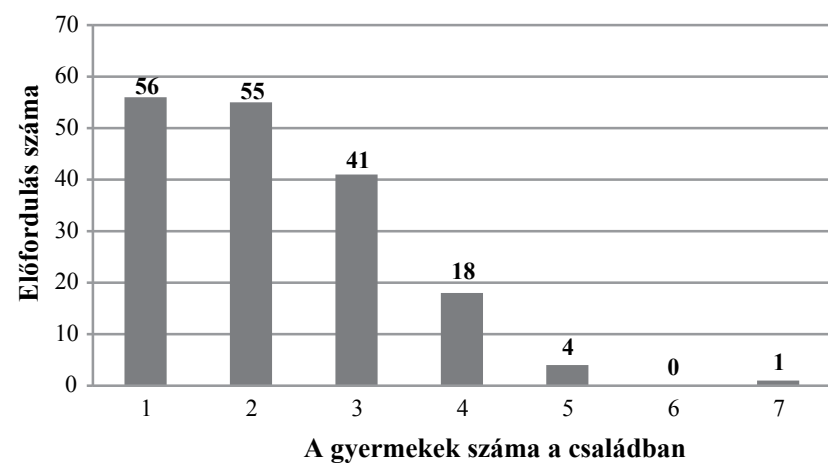

4. ábra | A gyermekek száma a vizsgálatban szereplő családok esetében

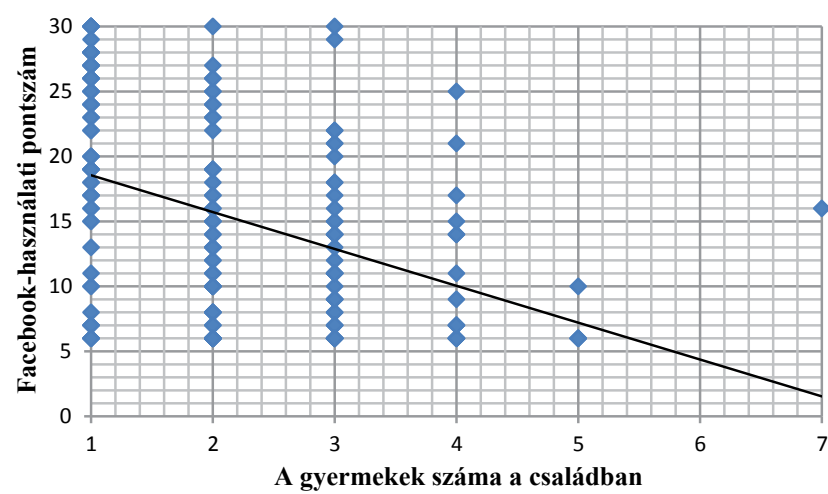

\begin{tabular}{l|l} 
5. ábra & $\begin{array}{l}\text { A Facebook-használat és gyermekek száma közötti korreláció } \\
(p=-0,400 ; p<0,01)\end{array}$
\end{tabular}

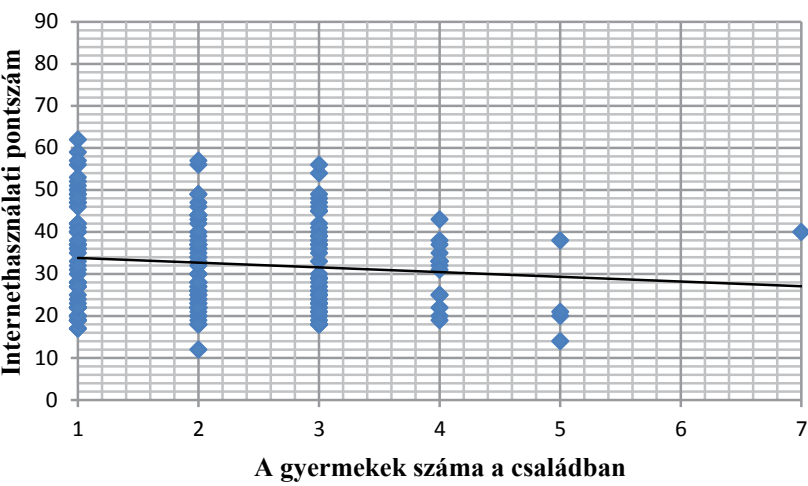

6. ábra

$$
\mid \begin{aligned}
& \text { Az internethasználat és a gyermekek száma közötti korreláció } \\
& (p=-0,110 ; p>0,14)
\end{aligned}
$$

ókat az 5. és 6. ábrán jelenítjük meg. Az eredmények azt mutatják, hogy az asztmás gyermekek Facebook-használata és a gyermekek száma a családban között negatív előjelú, közepes erősségű, jelentôs kapcsolat mutatható ki $(\rho=-0,400 ; p<0,01)$. Ez azt jelenti, hogy minél több testvére van az adott gyermeknek, annál kevesebbet használja a Facebookot. Mindezen összefüggés az internethasználat kapcsán nem mutatható ki. Az internethasználat és a gyermekek száma a családban között fordított irányú, elhanyagolható mértékủ a korreláció $(\rho=$ $-0,110 ; \mathrm{p}=0,146)$, azaz a testvérek száma nincs releváns befolyásoló hatással az illető internethasználatára. 


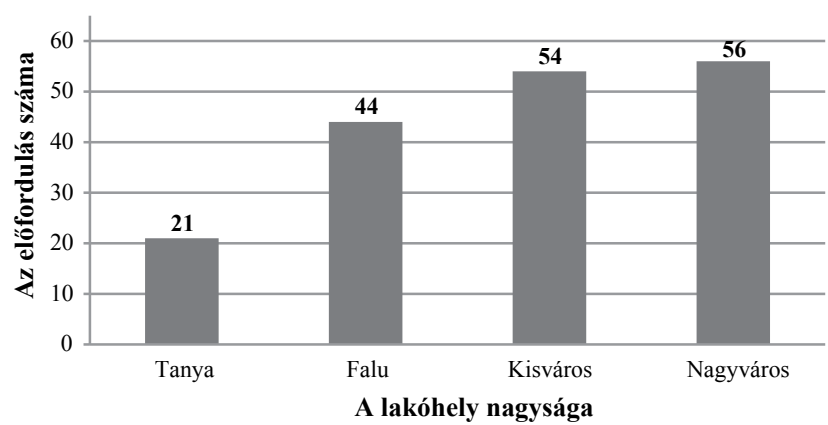

7. ábra $\mid$ A lakóhely szerinti megoszlás a vizsgálati mintában szerepló gyermekek esetében

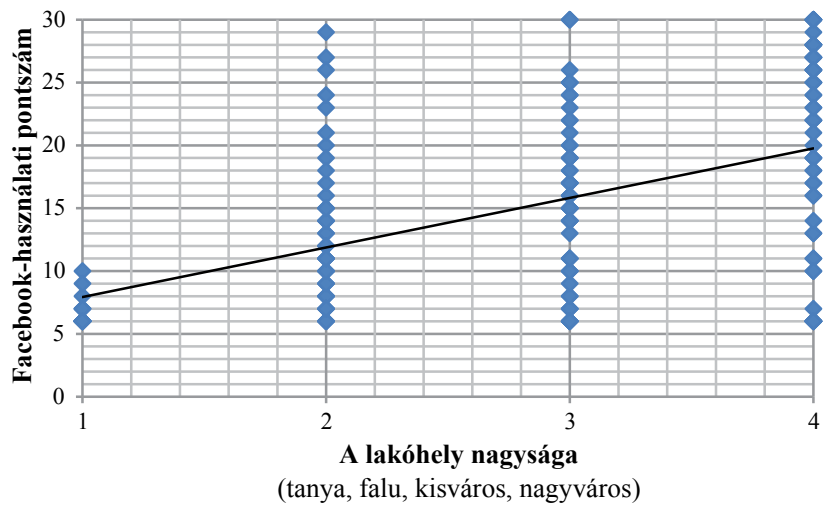

8. ábra $\mid \begin{aligned} & \text { A Facebook-használat és a lakóhely nagysága közötti korreláció } \\ & (p=0,492 ; p<0,01)\end{aligned}$

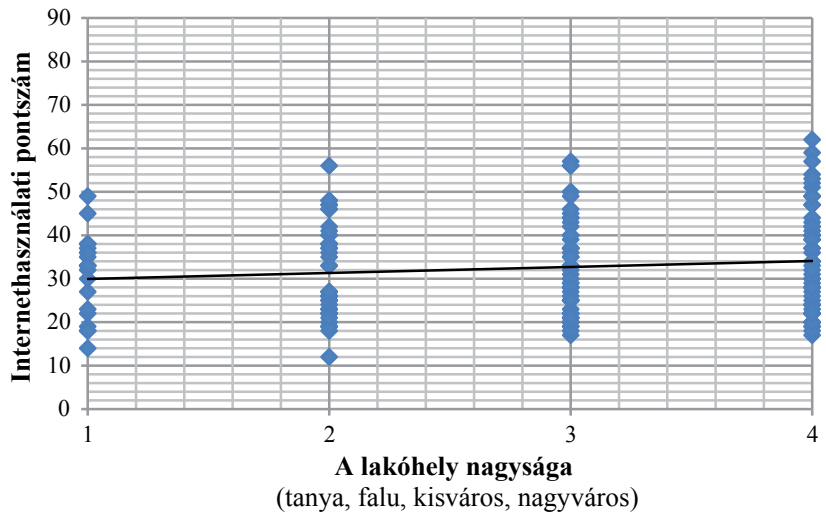

9. ábra

$$
\mid \begin{aligned}
& \text { Az internethasználat és a lakóhely nagysága közötti korreláció } \\
& (p=0,11 ; p>0,14)
\end{aligned}
$$

Az ötödik hipotézisünkben a vizsgálati minta lakóhely szerinti eloszlását a 7. ábrán szemléltetjük. Mivel az adatok esetében sérült a normalitáskövetelmény (ShapiroWilk-próba), így Spearman-felé rangkorrelációt kellett alkalmaznunk. A kapott korrelációk a hipotézisben megfogalmazottaknak megfelelően alakultak. Ezeket a 8. és 9. ábra mutatja. A lakóhely nagyságát 1-es, 2-es, 3-as, 4-es számmal jelöltük, ami a tanya, falu, kisváros, nagyváros felosztásnak felel meg. A kapott eredmények azt

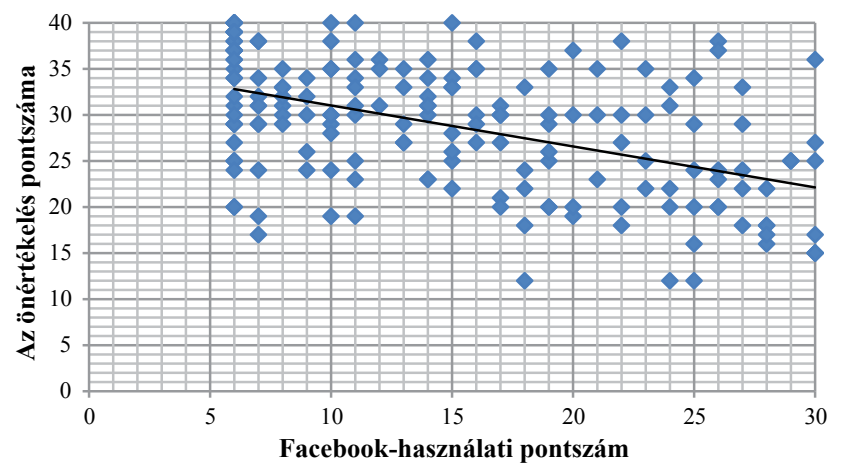

\begin{tabular}{l|l} 
10. ábra & $\begin{array}{l}\text { Az önértékelés és a Facebook-használat közötti korreláció } \\
(\rho=-0,475 ; p<0,01)\end{array}$
\end{tabular}

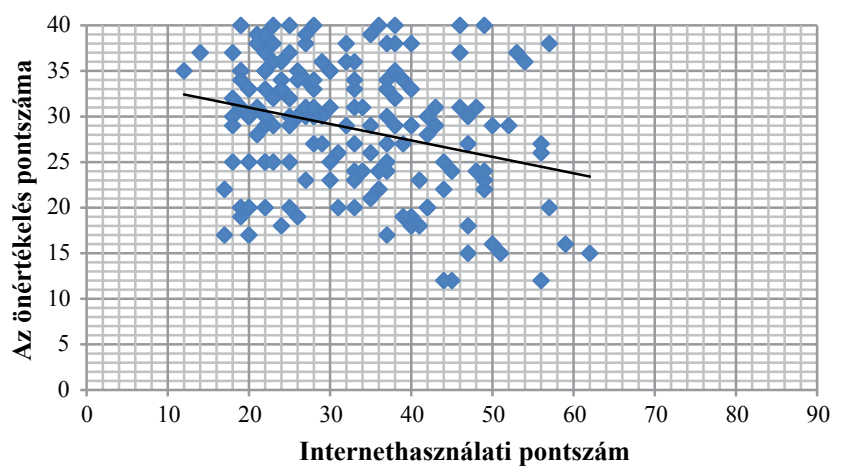

\begin{tabular}{l|l} 
11. ábra & $\begin{array}{l}\text { Az önértékelés és az internethasználat közötti korreláció } \\
(p=-0,243 ; p<0,01)\end{array}$
\end{tabular}

mutatják, hogy az asztmás gyermekek Facebook-használata és a lakóhelyük nagysága között közepes erősségű, szignifikáns kapcsolat mérhető $(p=0,492 ; p<0,01)$. Ennek alapján minél nagyobb településen lakik valaki, annál inkább használja a Facebookot. Mindezen összefüggés az internethasználat és a lakóhely nagysága között nem mutatható ki: a kapott korreláció elhanyagolható mértékúnek bizonyult $(\rho=0,110 ; p=0,145)$, azaz arra, hogy ki mennyit használja az internetet, nincs befolyással lakóhelyének nagysága.

A hatodik hipotézisünkben a korrelációk a vártnak megfelelő módon alakultak. Mivel adataink esetében sérült a normalitáskövetelmény (Shapiro-Wilk-próba), a Spearman-felé rangkorrelációt kellett alkalmaznunk. Az eredményeket a 10. és 11. ábrán szemléltetjük. A kapott eredmények alapján elmondható, hogy az önértékelés mértéke és a Facebook-használat között negatív előjelű, közepes erősségü, jelentős kapcsolat mutatható ki ( $p=$ $-0,475 ; \mathrm{p}<0,01)$. Mindez azt jelenti, hogy minél kisebb valakinek az önértékelése, annál magasabb Facebookpontszámmal jellemezhető, illetve minél inkább használja valaki a Facebookot, az önértékelése annál kisebb lesz (az ok-oksági viszony, ahogyan a szakirodalmi áttekintésben is utaltunk rá, circulus vitiosusként írható le). Az önértékelés és az internethasználat között negatív előjelű, gyenge, szignifikáns kapcsolat mutatható ki $(\rho=-0,243$; 
$\mathrm{p}<0,01)$. Mindez azt jelenti, hogy kisebb mértékben valósul meg az az összefüggés, amely szerint minél alacsonyabb valakinek az önértékelése, annál magasabb internethasználati pontszámmal jellemezhető.

\section{Megbeszélés}

Jelen vizsgálatunk eredményei fontos szempontokra mutathatnak rá. Az asthma bronchialéban szenvedő gyermekek 175 foos mintáján végzett kutatásunkban a szakirodalmi adatok mentén felállított hipotézisek a gyakorlatban is helytállónak bizonyultak. Ezen betegcsoport esetében lényeges, hogy a szomatikus tünetek hogyan fonódnak össze a lelki tényezőkkel, s a közösségimédia-használatukban, internetezési szokásaikban, önértékelésükben miként manifesztálódnak. Mint a kapott eredmények is mutatják, a fiúk közösségimédiahasználata szignifikánsan alacsonyabbnak bizonyult, mint a lányoké. Ennek oka az a nemi különbség lehet, amely az utóbbi csoport fokozott szociabilitásával, kapcsolatteremtési és kötődési hajlandóságával írható le. Emiatt a lányok fokozottabb veszélynek lehetnek kitéve, fóleg annak tudatában, hogy az önértékelésük is szignifikánsan alacsonyabb volt. Kiemelendő, hogy az önértékelés és a közösségimédia-használat között jelentős negatív korrelációt találtunk nemtől függetlenül, azaz aki többet használja a Facebookot, kevésbé pozitívan látja önmagát és fordítva. Itt a kauzalitás spirálként írható le, oda-vissza hatást feltételezve [44]. Olyan, a korai kötődésre jelentős befolyással lévő tényezők, mint a szoptatás időtartama és a bölcsődébe járás ideje, azt mutatják, hogy az ebből fakadó hiányok a későbbi életévekben jelentősen fogékonyabbá tehetik a gyermekeket a közösségi média nyújtotta szociális visszacsatolások (feedbackek) felé. Az anya-gyermek kapcsolat említett faktorait vizsgálva az eredmények azt mutatják, hogy már a rövid ideig (1-7 napig) tartó szoptatás is szignifikáns preventív faktor az asztmatikus gyermekek közösségimédia-használatával összefüggésben. A bölcsődébe járással kapcsolatban szintén elmondható, hogy az első életévekben történő intézménybe adás magasabb közösségimédia-használatot és alacsonyabb önértékelést eredményez, de szignifikáns negatív hatással akkor van, ha mindez egy hónapnál tovább áll fenn. Emellett a kapott adatok szerint akinek kevesebb testvére van, azaz kisebb mértékű nukleáris családbeli támogató közeggel rendelkezik e tekintetben, szignifikánsan többet használja a közösségi média világát. Hasonló tendenciát mutat a lakóhely típusával tett összevetésünk is: minél nagyobb településen lakik a gyermek, annál inkább jellemző rá a közösségimédia-használat. Mindez az élő kapcsolatok fontosságával és meglétével függhet össze, amelyek képesek védeni a virtuális világ kompenzatorikus álközösségi élményétől [45]. Az internethasználatra sem a testvérek száma, sem pedig a lakóhely nagysága nem volt érdemi befolyással.

Fontos kiemelnünk, hogy más krónikus betegcsoport esetében felvetették, hogy az internettel összefüggő ad- dikciónak lehetnek kitéve a betegségtudatuk és társas izolálódásuk miatt [46]. Emiatt tartjuk lényegesnek az eredményeinkből leszûrhető tapasztalatok felhasználhatóságát a preventív és korrektív ellátás területén. Úgy véljük, figyelmet kell fordítani a viktimizáció kérdéskörére is. A cyberbullying jelensége napjainkra olyan méreteket öltött, hogy szükséges intervenciók megfogalmazása a vulnerábilis betegcsoportok (és a sine morbo gyermekek) esetében [47]. Az életkori sajátosságokból fakadó, labilisabb önértékeléssel rendelkező 10-18 éves korosztály sérülékenyebb lehet ezen addiktív hatásokkal összefüggésben. Mivel a későbbi életkorokban több komorbid mentális rendellenesség is kialakulhat, a megelőzést, a pszichoedukációt célul tûzzük ki már a terhesség ideje alatt is. A kötődéssel kapcsolatos eredményeinket kiemelve, a kora gyermekkori élmények, az anya-gyermek kapcsolat, melynek a bölcsődébe adás és a szoptatás egyegy fontos jellemzője lehet, a legjobb asztmaprevencióként interpretálható. Ez - természetesen az anyatejben lévő biológiai tényezók mellett - a pszichológiai faktoroknak is köszönhető [48]. Ennek preventív jellege más, a kötődéssel, a haptonomikus ingerekkel relevánsan öszszeköthető betegségek esetében egyaránt megjelenhet [49]. Az érzelemkifejezés és -felismerés részben öröklött, részben szerzett nehézsége (alexithymia) szintén összefüggésbe hozható a kapott eredményeinkkel. Az asztmás gyermekek körében ennek - akár szubklinikus formában történő - megjelenése magasabb, ami hatékony segítségnyújtás nélkül szintén a virtuális világ fokozott használatára ösztönözheti őket, hiszen ott leegyszerüsített formájú emocionális közlések, visszacsatolások várják őket [50].

\section{Következtetés}

Elmondhatjuk, hogy a kapott adatok rámutattak kötődéssel és egészségmagatartással összefüggő tényezőkre az asthma bronchialéban szenvedő 10-18 éves korú gyermekek esetében. Lényegesnek tartottuk az ilyen megbetegedéssel küzdő gyermekek mintájának vizsgálatát, ugyanis ez vihet közelebb bennünket a zavar etiológiájának, fenomenológiájának és későbbi kezelésének megértéséhez. Az általunk adaptált Facebook Használati Kérdőív (FHK) jól illeszthető az elméleti keretrendszer vonatkozó részeihez. Vizsgálatunk korlátainak figyelembevételével (például a sine morbo kontrollcsoportnak a jelen kutatásbeli hiánya) az eredmények a gyakorlati felhasználhatóság felé mutatnak, és jövőbeli összehasonlító elemzések elvégzésére adnak okot.

Anyagi támogatás: A vizsgálat és a közlemény megírása anyagi támogatásban nem részesült.

Szerzői munkamegosztás: J. T.: Az elméleti háttér és a kutatási módszer kidolgozása, a vizsgálat lefolytatása, az adatok értelmezése, a statisztikai feldolgozás, a kézirat 
kialakítása és szövegezése. P. Á., G. F.: A vizsgálati alanyok toborzása. B. Gy.: Szakmai irányító. N. B. E.: A kutatási módszer kidolgozása és szupervíziója, az adatok értelmezése, a kézirat végső verziójának kialakítása. A cikk végleges változatát valamennyi szerző elolvasta és jóváhagyta.

\section{Érdekeltségek: A szerzőknek nincsenek érdekeltségeik.}

\section{Irodalom}

[1] Nagy LB. Phenotypes of bronchial asthma. [Az asthma bronchi ale fenotípusai.] Orv Hetil. 2017; 158: 491-498. [Hungarian]

[2] Wood BL, Miller BD, Lehman HK. Review of family relational stress and pediatric asthma: the value of biopsychosocial systemic models. Fam Process 2015; 54: 376-389.

[3] Juhn YJ. Influence of asthma epidemiology on the risk for other diseases. Allergy Asthma Immunol Res. 2012; 4: 122-131.

[4] Akinbami LJ, Simon AE, Rossen LM. Changing trends in asthma prevalence among children. Pediatr 2016; 137: e20152354.

[5] Papaiwannou A, Zarogoulidis P, Porpodis K, et al. Asthmachronic obstructive pulmonary disease overlap syndrome (ACOS): current literature review. J Thorac Dis. 2014; 6(Suppl 1): $146-151$.

[6] Haughney J, Morice A, Blyth KG, et al. A retrospective cohort study in severe asthma describing commonly measured biomarkers: eosinophil count and IgE levels. Respir Med. 2018; 134: $117-123$.

[7] Hamid QA, Minshall EM. Molecular pathology of allergic disease: I: lower airway disease. J Allergy Clin Immunol. 2000; 105: 20-36.

[8] Rosenberg SL, Miller GE, Brehm JM, et al. Stress and asthma: novel insights on genetic, epigenetic, and immunologic mechanisms. J Allergy Clin Immunol. 2014; 134: 1009-1015.

[9] Wenzel S, Ford L, Pearlman D, et al. Dupilumab in persistent asthma with elevated eosinophil levels. N Engl J Med. 2013; 368: 2455-2466.

[10] Haczku A, Panettieri RA Jr. Social stress and asthma: the role of corticosteroid insensitivity. J Allergy Clin Immunol. 2010; 125: $550-558$.

[11] Liu AH. Hygiene theory and allergy and asthma prevention. Paediatr Perinat Epidemiol. 2007; 21(Suppl 3): 2-7.

[12] Odler B, Müller V. Asthma-COPD overlap syndrome. [AsthmaCOPD overlap szindróma.] Orv Hetil. 2016; 157: 1304-1313. [Hungarian]

[13] McQuaid EL, Kopel SJ, Nassau JH. Behavioral adjustment in children with asthma: a meta-analysis. J Dev Behav Pediatr. 2001; 22: 430-439.

[14] Andrejkovics M, Gasparik É, Bokor P, et al. The new paradigm of medicine and of psychotherapy: the bio-psycho-socio-spiritual model. [Az orvoslás és a pszichoterápia új paradigmája: a biopszicho-szocio-spirituális modell.] Pszichoterápia 2013; 22: 9399. [Hungarian]

[15] Papp-Zipernovszky O, Náfrádi L, Schulz PJ, et al. "So each patient comprehends": measuring health literacy in Hungary. [ „Hogy minden beteg megértse!” - Az egészségmúveltség (health literacy) mérése Magyarországon.] Orv Hetil. 2016; 157: 905-915. [Hungarian]

[16] Endre L. Physical activity and bronchial asthma. [A testedzés és az asztma kapcsolata.] Orv Hetil. 2016; 157: 1019-1027. [Hungarian]

[17] Minuchin S, Fishman HC. Family therapy techniques. Harvard University Press, Cambridge, 2009.

[18] Carr A. The effectiveness of family therapy and systemic interventions for child-focused problems. J Fam Ther. 2009; 31: $3-45$.
[19] Dallos R, Vetere A. Systems theory, family attachments and processes of triangulation: Does the concept of triangulation offer a useful bridge? J Fam Ther. 2012; 34: 117-137.

[20] Nemes L. The child living inside us. [A bennünk élő gyermek.] Filum Kiadó, Budapest, 2000. [Hungarian]

[21] Klaniczay S. On childhood stuttering and the theory of clinging. J Child Psychother. 2000; 26: 97-115.

[22] Klopp A, Vehling L, Becker AB, et al. Modes of infant feeding and the risk of childhood asthma: a prospective birth cohort study. J Pediatr. 2017; 190: 192-199.e2.

[23] Eichhorn N. Maternal fetal attachment: can acceptance of fetal sentience impact the maternal-fetal attachment relationship? J Prenat Perinat Psychol Health 2012; 27: 47-55.

[24] Trevarthen C. What is it like to be a person who knows nothing? Defining the active intersubjective mind of a newborn human being. Inf Child Dev. 2011; 20: 119-135.

[25] Lee KT, Noh MJ, Koo DM. Lonely people are no longer lonely on social networking sites: the mediating role of self-disclosure and social support. Cyberpsychol Behav Soc Netw. 2013; 16: 413-418.

[26] Kopp MS, Skrabski Á, Szedmák S. Psychosocial risk factors, inequality and self-rated morbidity in a changing society. Soc Sci Med. 2000; 51: 1351-1361

[27] Vanderbilt-Adriance E, Shaw DS, Brennan LM, et al. Protective factors in the development of children's early conduct problems. Fam Relat. 2015; 64: 64-79.

[28] Ferguson CJ. Do angry birds make for angry children? A metaanalysis of video game influences on children's and adolescents' aggression, mental health, prosocial behavior and academic performance. Perspect Psychol Sci. 2015; 10: 646-666.

[29] Özgür H. The relationship between Internet parenting styles and Internet usage of children and adolescents. Comput Hum Behav. 2016; 60: 411-424.

[30] Song H, Zmyslinski-Seelig A, Kim J, et al. Does Facebook make you lonely? A meta-analysis. Comput Hum Behav. 2014; 36: 446-452.

[31] Dhir A, Chen GM, Chen S. Why do we tag photographs on Facebook? Proposing a new gratifications scale. N Med Soc. 2017; 19: 502-521.

[32] Wang JL, Jackson LA, Wang HZ, et al. Predicting social networking site (SNS) use: personality, attitudes, motivation and internet self-efficacy. Person Individ Diff. 2015; 80: 119-124.

[33] Wan CS, Chiou WB. Why are adolescents addicted to online gaming? An interview study in Taiwan. Cyberpsychol Behav. 2006; 9: 762-766.

[34] Józsa T, Nagy BE. Media and internet usage as a behavior connected with attachment among asthmatic youth. In: Koncz I, Száva I. (eds.) Professors for the European Hungary Foundation's studies I. [A média- és internethasználat mint a kötődéssel összefüggő magatartásforma asztmatikus fiatalok körében. In: Koncz I, Száva I. (szerk.) Professzorok az Európai Magyarországért Egyesület tanulmánykötet I.] Elektronikus könyv, Budapest, 2017; pp. 243-246. [Hungarian]

[35] Marino C, Gini G, Vieno A, et al. A comprehensive meta-analysis on Problematic Facebook Use. Comput Hum Behav. 2018; 83: 262-277.

[36] Chen E, Miller GE. Stress and inflammation in exacerbations of asthma. Brain Behav Immun. 2007; 21: 993-999.

[37] Kozyrskyj AL, Mai XM, McGrath P, et al. Continued exposure to maternal distress in early life is associated with an increased risk of childhood asthma. Am J Respir Crit Care Med. 2008; 177: 142-147.

[38] Ko CH, Yen JY, Yen CF, et al. Factors predictive for incidence and remission of internet addiction in young adolescents: a prospective study. Cyberpsychol Behav. 2007; 10: 545-551.

[39] Anderson EL, Steen E, Stavropoulos V. Internet use and problematic internet use: A systematic review of longitudinal research trends in adolescence and emergent adulthood. Int J Adolesc Youth 2017; 22: 430-454. 
[40] Zywica J, Danowski J. The faces of Facebookers: investigating social enhancement and social compensation hypotheses; predicting Facebook and offline popularity from sociability and selfesteem, and mapping the meanings of popularity with semantic networks. J Comput-Med Commun. 2008; 14: 1-34.

[41] Ellison NB, Steinfield C, Lampe C. The benefits of Facebook "friends": social capital and college students' use of online social network sites. J Comput-Med Commun. 2007; 12: 1143-1168.

[42] Demetrovics Zs, Szeredi B, Nyikos E. Introduction of the Problem Internet Use Questionnaire. [A Problémás Internethasználat Kérdő́iv bemutatása.] Psychiatr Hung. 2004; 19: 141-160. [Hungarian]

[43] Rózsa S, Komlósi A. Psychometric analysis of Rosenberg SelfEsteem scale: item-wording, dimensionality and item characteristics. [A Rosenberg Önbecsülés Skála pszichometriai jellemzői: a pozitívan és negatívan megfogalmazott tételek múködésének sajátosságai.] Pszichológia 2014; 34: 149-174. [Hungarian]

[44] Gangadharbatla H. Facebook me: collective self-esteem, need to belong, and internet self-efficacy as predictors of the iGeneration's attitudes toward social networking sites. J Interact Advert. 2008; 8: 5-15.

[45] Kim J, LaRose R, Peng W. Loneliness as the cause and the effect of problematic Internet use: the relationship between Internet use and psychological well-being. Cyberpsychol Behav. 2009; 12: 451-455.

[46] Fox S, Purcell K. Chronic disease and the Internet. Pew Internet \& American Life Project, Washington DC, 2016.

[47] Ferrara P, Ianniello F, Villani A, et al. Cyberbullying a modern form of bullying: Let's talk about this health and social problem. Ital J Pediatr. 2018; 44: 14.

[48] den Dekker HT, Sonnenschein-van der Voort AM, Jaddoe VW, et al. Breastfeeding and asthma outcomes at the age of 6 years: the Generation R study. Pediatr Allergy Immunol. 2016; 27: 486-492.

[49] Lodge CJ, Tan DJ, Lau MXZ. Breastfeeding and asthma and allergies: a systematic review and meta-analysis. Acta Paediatr. 2015; 104(Suppl. 467): 38-53.

[50] Chugg K, Barton C, Antic R, et al. The impact of alexithymia on asthma patient management and communication with health care providers: a pilot study. J Asthma 2009; 46: 126-129.

(Józsa Tamás,

Debrecen, Diófa u. 31/A, 4031

e-mail: tamasjozsa@med.unideb.hu)

\section{Rácz Károly Endokrinológiai továbbképző tanfolyam \\ 14. Endokrinológiai továbbképző tanfolyam \\ Budapest, 2018. november 29. - december 1. NOVOTEL Centrum, 1088 Budapest, Rákóczi út 43-45.}

A Semmelweis Egyetem II. Belgyógyászati Klinikája és a Magyar Endokrinológiai Társaság közös szakmai fóruma, az Endokrinológiai továbbképző tanfolyam ebben az évben 14. alkalommal kerül megrendezésre. Az első 12 tanfolyam fő szervezője Dr. Rácz Károly professzor úr volt. Sajnálatosan korai halála miatt ez lesz a második olyan tanfolyam, amit Professzor úr részvétele nélkül kell megrendeznünk. Emlékének adózva a tanfolyamot

\section{Rácz Károly Endokrinológiai továbbképző tanfolyamnak nevezzük.}

Az eddigi évek sikeres tanfolyamainak hagyományát folytatva a tanfolyam fö céljának továbbra is a korszerü, a klinikai gyakorlatban is használható ismeretek átadását tekintjük.

A fö hangsúlyt a gyakori betegségek korai felismerésére és kezelésére helyezzük, de több ritka, érdekes kórkép bemutatását is tervezzük.

Az endokrinológusok mellett számítunk az endokrinológia és az anyagcsere-betegségek iránt érdeklő családorvos, belgyógyász, gyermekgyógyász és szülész-nögyógyász szakorvos kollégák részvételére is.

A korszerű kezelési lehetőségek bemutatására több szimpóziumot is tervezünk. Tanfolyamunkon két kiemelkedő nemzetközi elöadó is tart előadást.

A tanfolyam végén, hagyományainkhoz híven, tanulságos eseteken keresztül mutatjuk be az endokrinológia szépségeit.

A tanfolyam kreditpontos és tesztvizsgával zárul.

A továbbképző tanfolyam orvosok részére SE-TK/2018.II/00275 kódszámon akkreditált. Sikeres tesztírással az orvos résztvevők 44 kreditpontot szerezhetnek. A kreditpontok az OFTEX portálokon feltüntetett szakképesítéseknél szakma szerinti kötelező pontszámként kerülnek jóváírásra.

Reméljük, hogy a Rácz Károly Endokrinológiai továbbképzö tanfolyam résztvevőiként üdvözölhetjük Önöket.

Kollegiális üdvözlettel, a tanfolyam szervezői:

$$
\text { Dr. Igaz Péter }
$$

Dr. Tóth Miklós

Tudományos információ:

Dr. Igaz Péter igazgató, egyetemi tanár, az MTA doktora Semmelweis Egyetem, Általános Orvostudományi Kar,

II. Belgyógyászati Klinika

e-mail: igaz.peter@med.semmelweis-univ.hu
Dr. Tóth Miklós egyetemi tanár, az MTA doktora Semmelweis Egyetem, Általános Orvostudományi Kar, II. Belgyógyászati Klinika e-mail: toth.miklos@med.semmelweis-univ.hu

\section{Szervezési információ:}

Horvát Renáta - Convention Budapest Kft., együttmüködő partner

Telefon: +36 30 721-3713

e-mail: rhorvat@convention.hu; www.convention.hu 